\title{
Drilling to investigate processes in active tectonics and magmatism
}

\author{
J. Shervais ${ }^{1}$, J. Evans ${ }^{1}$, V. Toy ${ }^{2}$, J. Kirkpatrick ${ }^{3}$, A. Clarke $^{4}$, and J. Eichelberger ${ }^{5}$ \\ ${ }^{1}$ Utah State University, Logan, Utah 84322, USA \\ ${ }^{2}$ University of Otago, P.O. Box 56, Dunedin 9054, New Zealand \\ ${ }^{3}$ Colorado State University, Fort Collins, Colorado 80524, USA \\ ${ }^{4}$ Arizona State University, Tempe, Arizona 85287, USA \\ ${ }^{5}$ University of Alaska, Fairbanks, Fairbanks, Alaska 99775, USA \\ Correspondence to: J. Shervais (john.shervais@usu.edu)
}

Received: 7 January 2014 - Revised: 5 May 2014 - Accepted: 19 May 2014 - Published: 22 December 2014

\begin{abstract}
Coordinated drilling efforts are an important method to investigate active tectonics and magmatic processes related to faults and volcanoes. The US National Science Foundation (NSF) recently sponsored a series of workshops to define the nature of future continental drilling efforts. As part of this series, we convened a workshop to explore how continental scientific drilling can be used to better understand active tectonic and magmatic processes. The workshop, held in Park City, Utah, in May 2013, was attended by 41 investigators from seven countries. Participants were asked to define compelling scientific justifications for examining problems that can be addressed by coordinated programs of continental scientific drilling and related site investigations. They were also asked to evaluate a wide range of proposed drilling projects, based on white papers submitted prior to the workshop.

Participants working on faults and fault zone processes highlighted two overarching topics with exciting potential for future scientific drilling research: (1) the seismic cycle and (2) the mechanics and architecture of fault zones. Recommended projects target fundamental mechanical processes and controls on faulting, and range from induced earthquakes and earthquake initiation to investigations of detachment fault mechanics and fluid flow in fault zones. Participants working on active volcanism identified five themes: the volcano eruption cycle; eruption sustainability, near-field stresses, and system recovery; eruption hazards; verification of geophysical models; and interactions with other Earth systems. Recommended projects address problems that are transferrable to other volcanic systems, such as improved methods for identifying eruption history and constraining the rheological structure of shallow caldera regions. Participants working on chemical geodynamics identified four major themes: large igneous provinces (LIPs), ocean islands, continental hotspot tracks and rifts, and convergent plate margins (subduction zones).

This workshop brought together a diverse group of scientists with a broad range of scientific experience and interests. A particular strength was the involvement of both early-career scientists, who will initiate and carry out these new research programs, and more senior researchers with many years of experience in scientific drilling and active tectonics research. Each of the themes and questions outlined above has direct benefits to society, including improving hazard assessment, direct monitoring of active systems for early warning, renewable and non-renewable resource and energy exploitation, and predicting the environmental impacts of natural hazards, emphasizing the central role that scientific drilling will play in future scientific and societal developments.
\end{abstract}




\section{Introduction}

Forces originating deep within the active Earth are expressed at Earth's surface, where they have a profound effect on human societies. On a global scale, these effects include the development of mountain ranges, rift valleys and subduction zones. On a local scale, they are expressed as active faults (with slip ranging from a few meters to hundreds of kilometers) and volcanoes (ranging from individual volcanoes to large volcanic chains or fields). Both earthquakes and volcanic eruptions have caused significant loss of life and economic losses in recent times. Key measurements of the forces and energy driving these dynamic systems are missing, hindering progress towards physically based models that can be used to predict natural system behavior.

Understanding how fault systems and volcanoes operate is therefore crucial to mitigating these hazards. Unfortunately, studying active systems is difficult because earthquake nucleation and propagation, as well as crucial magmatic processes, take place at depth, obscured from simple observational techniques. Although deeper parts of faults and volcanic plumbing systems may be exposed by erosion in older terranes, information on active processes can only be inferred because critical relationships are still hidden beneath the Earth's surface. Deep scientific drilling is established as one of the most powerful techniques for investigating these active fault zones and magmatic systems (Harms et al., 2007).

To establish ways in which continental scientific drilling (CSD) can be used to address these critical societal issues, a workshop was held in Park City, Utah, in May 2013, sponsored by the US National Science Foundation (NSF), and attended by 41 investigators in active tectonics and magmatism. Although emphasis was placed on our goal of helping to define a US-based program of continental scientific drilling, participants included representatives from Canada, India, Italy, Japan, Great Britain, and New Zealand, who are actively engaged in international research efforts in cooperation with US-based investigators. Here, we summarize the key findings from the workshop, and present a series of investigator-driven ideas for future research. We hope that the results from this workshop can act both as a guide and source of motivation for renewed community interest in scientific drilling.

\subsection{Workshop organization}

Participants were asked to define significant scientific questions related to active tectonics and magmatic processes that can only be addressed by a coordinated program of continental scientific drilling and related site investigations. Workshop participants were also asked to prioritize these ideas, and to propose specific faults and volcanoes that would be targeted by these efforts.

Our goal for this workshop was to provide a road map of specific science projects and objectives that address the most pressing issues in active tectonics and magmatism that can be addressed by drilling.

White papers on specific drilling targets and projects submitted prior to the meeting focused discussions on particular locations where major problems could be addressed (white papers can be accessed at http://digitalcommons.usu.edu/ geology_facpub/386/). At the workshop, participants discussed the scientific motivations for these proposed projects and their corresponding target sites, and attempted to prioritize them based on the strength of the science drivers, and on their readiness for formal review. Many of these proposed efforts are interdisciplinary, are directly related to ongoing NSF programs and consortia (e.g., Geodynamic Processes at Rifting and Subducting Margins: GeoPRISMS; Incorporated Research Institutions for Seismology: IRIS; Earthscope), and apply to a range of scales, from localized fault systems to plate boundary faults, and from small monogenetic vents to super-volcanoes. Some projects are being supported in part by other US federal agencies, e.g., US Geological Survey and US Department of Energy, or internationally (e.g., drilling in the Deccan Traps, as discussed below). All of the white papers propose to interrogate fundamental processes in geosciences and so are transferable globally.

The workshop spanned two full days of meetings. On the first morning, keynote speakers presented talks on "Trends and Topics" in scientific drilling of faults and volcanoes (see Table 1 and Fig. 1). This was followed in the afternoon and on the morning of day two by short talks $(5-10 \mathrm{~min})$ by workshop participants highlighting their white papers. The remainder of day two was devoted to breakout groups on faults, fault processes, active volcanism, and chemical geodynamics as expressed by volcanic terranes. At the end of day two, scribes from each breakout group presented summaries of their findings. The summary of this work is provided in Shervais et al. (2013a).

\subsection{Building on past success}

Deep continental drilling has successfully addressed longstanding problems in active tectonics, and some of continental drilling's most successful projects have grown out of issues related to active processes in faults and volcanoes, and those related to chemical geodynamics of the Earth. The success of these projects demonstrates the effectiveness of continental scientific drilling, and these projects formed the basis for some of the new projects proposed and discussed at this workshop. Drilling projects that have addressed the mechanics of faulting and fault zone processes include the San Andreas Fault Observatory at Depth (SAFOD: Zoback et al., 2010, 2011); the Chelungpu Fault (Taiwan) Drilling Project (Ma et al., 2006, 2012); the Alpine Fault (New Zealand) Deep Fault Drilling Project (Towend et al., 2009); the Nojima Fault Drilling Project (Ando, 2001); the Wenchuan, China Project (Xu et al., 2009); and (within the oceanic realm) the NanTroSeize project to drill faults within 
Table 1. List of white papers prepared for the workshop, and published through USU Digital Commons portal: http://digitalcommons.usu. edu/geology_facpub/386/.

\begin{tabular}{|c|c|}
\hline $\begin{array}{l}\text { Evolution of fault zone geology in an active continental rift: scientific } \\
\text { drilling opportunities along the Sangre de Cristo fault system, northern Rio } \\
\text { Grande rift, Colorado }\end{array}$ & L. B. Ball, J. S. Caine, V. J. S. Grauch, C. A. Ruleman \\
\hline $\begin{array}{l}\text { Capturing the seismic cycle: sampling and instrumenting an earthquake nu- } \\
\text { cleation patch }\end{array}$ & B. Carpenter, J. Chester, and S. Hickman \\
\hline $\begin{array}{l}\text { Reconstructing an "A-type" silicic magma system along the track of the } \\
\text { Yellowstone Hotspot, central Snake River Plain, Idaho }\end{array}$ & E. H. Christiansen and the Hotspot Science Team \\
\hline $\begin{array}{l}\text { Testing the extensional detachment paradigm: a borehole observatory in the } \\
\text { Sevier Desert Basin }\end{array}$ & $\begin{array}{l}\text { N. Christie-Blick, M. H. Anders, G. Manatschal, and B. } \\
\text { P. Wernicke }\end{array}$ \\
\hline $\begin{array}{l}\text { Understanding the evolution of a back-arc bimodal shield volcano, New- } \\
\text { berry Volcano, Oregon }\end{array}$ & Z. Frone \\
\hline $\begin{array}{l}\text { Volcano structure and Hawaiian plume heterogeneity based on new drilling } \\
\text { of Mauna Kea }\end{array}$ & $\begin{array}{l}\text { M. Garcia, D. Depaolo, E. Haskins, N. Lautze, J. M. } \\
\text { Rhodes, and D. Thomas }\end{array}$ \\
\hline Coring and studying clay gouges from mature active fault zones & J. Hadizadeh, T. Candela, J. C. White, and F. Renard \\
\hline $\begin{array}{l}\text { Isotope geochemistry and mantle source regions for plume-lithosphere in- } \\
\text { teraction }\end{array}$ & B. B. Hanan \\
\hline $\begin{array}{l}\text { A proposal to drill active faults and magmatism in a major intracontinental } \\
\text { fault zone, Mono Lake Basin, Walker Lane, western Great Basin, USA }\end{array}$ & A. S. Jayko and S. Martel \\
\hline $\begin{array}{l}\text { Koyna - Warna Seismic Zone, Western India: a unique intraplate setting for } \\
\text { drilling for an active fault zone underlying a basaltic pile }\end{array}$ & Vivek S. Kale \\
\hline $\begin{array}{l}\text { Geological } \mathrm{CO}_{2} \text { Storage: constraints from scientific drilling of natural } \mathrm{CO}_{2} \\
\text { reservoirs, leaky faults and travertine deposits of the Colorado Plateau }\end{array}$ & $\begin{array}{l}\text { N. Kampman, M. Bickle, J. Evans, D. Condon, C. Bal- } \\
\text { lentine, G. Holland, Z. Zhou, Z. Shipton, M. Schaller, } \\
\text { C. Rochelle, and J. Harrington }\end{array}$ \\
\hline Enhancing data management for continental scientific drilling & K. Lehnert and A. Noren \\
\hline Mechanics of normal fault systems & S. J. Martel \\
\hline Sampling and in-situ Observations of Okmok (SINOOK) & $\begin{array}{l}\text { T. Masterlark, J. Eichelberger, J. Freymueller, M. } \\
\text { Haney, S. Hurwitz, P. Izbekov, J. Larsen, S. Nakada, C. } \\
\text { Neal, W. Roggenthen, and C. Thurber }\end{array}$ \\
\hline
\end{tabular}

Study of the thermo-mechanical aspects of extensional fault systems by E. Miller and J. Lee shallow continental scientific drilling into paleo brittle-ductile transition zones and top of channel flow in the Basin and Range Province, USA

\begin{tabular}{|c|c|}
\hline Large igneous provinces (LIPs) and the IODP connection & C. R. Neal \\
\hline $\begin{array}{l}\text { Drilling investigations on the mechanics of faults: downhole measurements } \\
\text { to detect time variation of in-situ stress }\end{array}$ & K. Omura \\
\hline Project HOTSPOT: investigating subsurface basalt using wireline logs & K. Potter \\
\hline $\begin{array}{l}\text { Proposal to drill into the Puysegur Subduction Zone: investigating the com- } \\
\text { plex role of peridotite and serpentinite in the seismicity of the subduction } \\
\text { zone interface }\end{array}$ & L. A. Reinen and V. G. Toy \\
\hline Mauna Loa: drilling the other side of the Hawaiian plume & J. M. Rhodes, F A. Trusdell, and M. O. Garcia \\
\hline Earthquake triggering and fault zone drilling & H. Savage, N. Van Der Elst, and J. Kirkpatrick \\
\hline $\begin{array}{l}\text { Borehole geophysics - applications and limitations in extreme environ- } \\
\text { ments }\end{array}$ & D. R. Schmitt and M. D. Lee \\
\hline $\begin{array}{l}\text { Drilling the Josephine Ophiolite - direct observation of a subduction zone } \\
\text { mantle wedge }\end{array}$ & J. W. Shervais and H. J. B. Dick \\
\hline Tracking the Yellowstone Hotspot through space and time & $\begin{array}{l}\text { J. W. Shervais, B. B. Hanan, E. H. Christiansen, S. R. } \\
\text { Schmitt, and the Hotspot Science Team }\end{array}$ \\
\hline $\begin{array}{l}\text { Alpine Fault - Deep Fault Drilling Project (DFDP), New Zealand: current } \\
\text { and future opportunities for active US participation in an international con- } \\
\text { tinental fault zone drilling project }\end{array}$ & V. G. Toy, J. Townend, and R. Sutherland \\
\hline $\begin{array}{l}\text { Magmatic-hydrothermal transitions in active extensional regimes of the } \\
\text { western U.S.: the need for drilling to assess physico-chemical state }\end{array}$ & P. Wannamaker \\
\hline
\end{tabular}




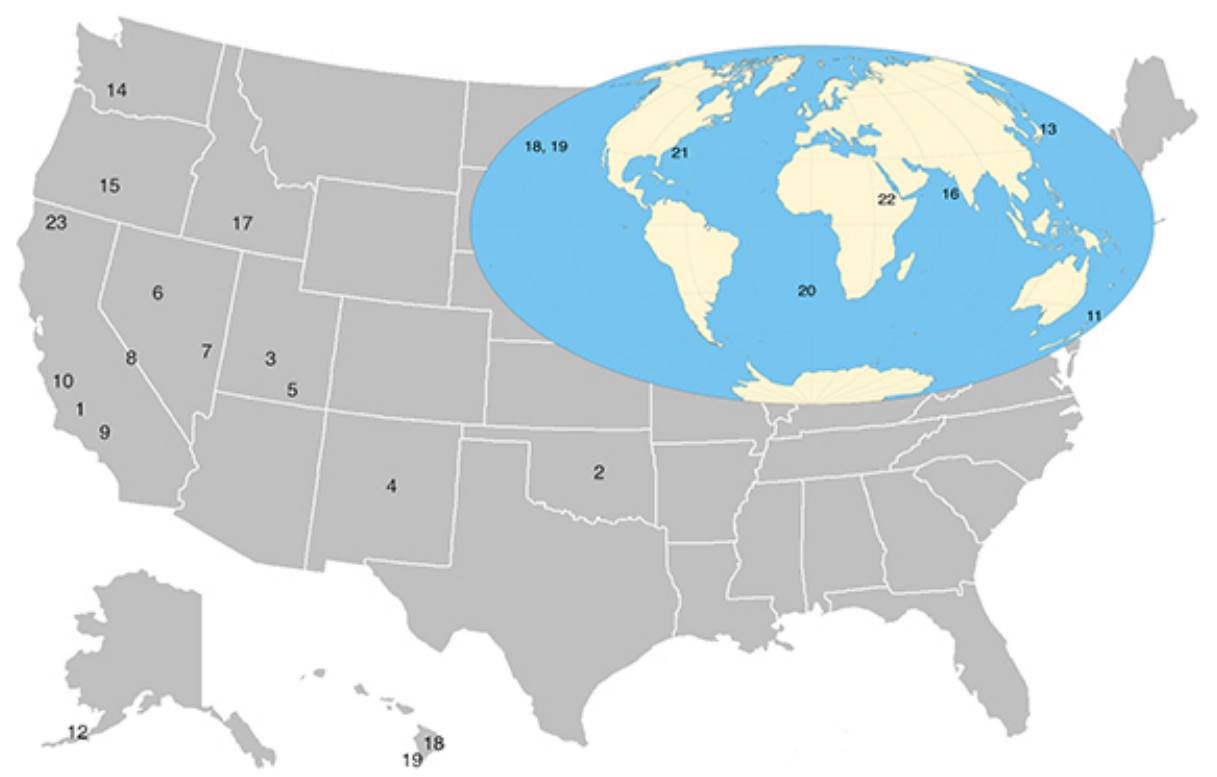

Figure 1. Map of USA and inset map of the world with recommended projects and alternate projects marked (Table 2). Projects 1-11 relate to fault zone drilling, projects 12-15 to active volcanic systems, and projects 16-23 to chemical geodynamics.

an accretionary prism (Tobin et al., 2006, 2009) and the Japan Trench Fast Drilling Project (JFAST) that sampled the seismically active plate boundary at the Japan trench (Chester et al., 2013). Drilling projects that addressed the origin, evolution, or eruptive mechanisms of volcanoes or young active volcanic terranes include the Mt. Unzen Scientific Drilling Project (Nakada et al., 2005) and the Iceland Deep Drilling Project (IDDP: Friðleifssona et al., 2014; Elders et al., 2014). Projects focusing on chemical geodynamics include the Hawai'i Scientific Drilling Project (DePaolo et al., 1996, 2007) and Hotspot: the Snake River Drilling Project (Shervais et al., 2006, 2013b).

\section{Broader context}

Continental scientific drilling is a tool for studying processes that cannot be accessed through normal surfacebased investigations. In the US, it complements existing NSF programs such as GeoPRISMS, Earthscope, Frontiers in Earth System Dynamics (FESD), Integrated Earth Systems (IES), Critical Zone Observatory (CZO), Petrology and Geochemistry, Tectonics, and Paleo Perspectives on Climate Change (P2C2). Scientific drilling is also an important component of other agency programs, such as the U.S. Geological Survey (USGS: e.g., fault zone drilling, geothermal energy, oil and gas assessments, water resources research), the Department of Energy (DOE: e.g., geothermal energy, $\mathrm{CO}_{2}$ sequestration, oil and gas research) and the Department of Defense (DOD: e.g., geothermal energy). As a result, the science drivers for continental scientific drilling overlap with the science objectives in these other agencies.

\subsection{Science drivers for continental scientific drilling}

Scientific drilling provides unique access to dynamic tectonic environments and samples, and allows us to examine active processes before they are overprinted or altered during exhumation (e.g., Ito et al., 2007; Zoback et al., 2011; Eichelberger and Uto, 2007). Installation of borehole observatories enables monitoring of in situ geophysical, geochemical, mechanical, physical, and hydrological conditions, and their evolution over time. Drilling, sampling, and downhole measurements, in concert with surface-based geophysical imaging, make it possible to characterize variations in geologic structure, rock and fluid composition, and rock physical properties in three dimensions around fault zones and volcanoes. Further, it is often possible to sample rock that is actively deforming at conditions not found in the near surface (e.g., those with a temperature-dependent rheology), and then study the deformational behavior of these samples in the laboratory at realistic conditions of temperature, pressure, and fluid chemistry.

Active magmatic systems (volcanoes) are extremely challenging environments for drilling. They are characterized by high temperatures, corrosive gasses and fluids, and wide variations in physical rock properties. Nonetheless, drilling into active volcanoes can be highly rewarding scientifically. The motivations for scientific drilling into active volcanic systems have been discussed by Eichelberger and Ito (2007). These include (a) sampling of deep uncontaminated materials (rocks, fluids, and gases); (b) studying hydrothermal alteration; (c) sampling quenched magmas; (d) measuring state of stress associated with magmatic systems; (e) delineating the geometry and thermal regime of magmatic and hydrothermal 
Table 2. Potential projects recommended by the participants, and other potential projects. Author(s) of relevant white paper listed in parentheses.

\title{
Faults and fault mechanics
}

A. Understanding the seismic cycle

1. Reoccupying and extending the SAFOD site (Carpenter et al.)

2. Triggering earthquakes for science (Savage et al.)

B. 4-dimensional mechanics and architecture of fault zones

3. Mechanics of the Sevier detachment (Christie-Blick et al.)

4. Tectonic evolution and mechanics of the Rio Grande rift (Ball et al.)

5. Fluid flow and supercritical fluid-rock interactions in the Little Grand Wash fault (Kampman et al.)

C. Faults: other potential targets

6. Dixie Valley (Wannamaker)

7. The Snake Range Detachment fault zone (Miller and Lee)

8. Mono Basin (Jayko et al.)

9. The San Andreas fault near Little Rock

10. The San Andreas fault at San Juan Bautista (Hadizadeh et al.)

11. The Puysegur Subduction Zone (Reinen and Toy)

\begin{tabular}{l} 
Active magmatic systems \\
\hline 12. Okmok Volcano, Alaska, USA (Masterlink et al.) \\
13. Aso Caldera, Japan (Nakada) \\
14. Mount St. Helens, Washington, USA \\
15. Newberry Volcanic Monument, Oregon, USA (Frone)
\end{tabular}

Geodynamic and geochemical evolution of earth

16. Deccan Traps, India: US Participation in the Indian Koyna Drilling Project and Joint ICDP-IODP Drilling of the DeccanReunion Hotspot track (Kale and Neal)

17. Snake River Plain Continental Plume Track (Christiansen et al., Shervais et al., Hanan et al., Potter et al., Schmitt and Lee)

18. Mauna Kea PTA Project (Garcia et al.)

19. Mauna Loa Project (Rhodes et al.)

\section{Other potential geodynamic targets}

\author{
20. Etendeka-Walvis Ridge \\ 21. CAMP: The Central Atlantic Magmatic Province, On-shore and Off-shore \\ 22. Ethiopian Traps \\ 23. Josephine Ophiolite -Direct Observation of a Subduction Zone Mantle Wedge (Shervais and Dick)
}

plumbing systems; (f) measuring physical properties in zones of active deformation and seismicity associated with magma intrusion and volatile release; and (g) determining variations in temperature, deformation, and fluid composition over time, which may require installation of borehole observatories.

Chemical geodynamics of the mantle (i.e., the creation of physically distinct mantle reservoirs with different geochemical and isotopic compositions) may be investigated in part by studying hotspots, subduction zones, and rifts. The connection between deep-seated mantle plumes, ocean island basalts, and large igneous provinces (LIPs) is now supported by new techniques in mantle tomography that establish visible connections between hotspot volcanoes and deep thermal anomalies (DePaolo and Weiss, 2007). The formation of LIPs may also have significant impact on short-term climate change, which can affect biotic evolution and extinctions, and in some cases may be tied to Ocean Anoxic Events (Tejada et al., 2009; Erba et al., 2010). Scientific drilling can provide long-term stratigraphic records that record the evolution of these magmatic systems over time, their precise age ranges and duration, and evidence for biotic overturn, providing direct linkages to climatic records. The recovery of unweathered samples through continuous coring is critical for resolving many of the questions discussed in detail below.

\subsection{Integration with IODP}

Active tectonic and volcanic processes affect oceanic crust continental crust, and drive the processes at plate boundaries. 
Because of this, participants concluded that better integration is needed between CSD worldwide and the International Ocean Discovery Program (IODP). Although some fault zone processes projects already involve onshore and offshore components (e.g., NantroSEIZE, Alpine Fault - DFDP, proposed Hikurangi margin drilling; see also Ito et al., 2007), there is little coordination between IODP and continental drilling projects that address active magmatism or chemical geodynamics. The close genetic relationship among continental flood basalts (CFBs), LIPs, and ocean island chains presents a unique opportunity for linkages between CSD and IODP. These linkages were highlighted at an NSF-IODP workshop held in Colraine, Northern Ireland, in 2006 (Neal et al., 2008). They include onshore-offshore linkages between CFBs and their related "plume tail" oceanic tracks, the onset of continental rifting, and syn-LIP sedimentation (which preserves the onset of LIP eruptions).

\subsection{Integration with other drilling programs}

Continental scientific drilling projects are commonly conducted through collaborations among multiple agencies. In some cases, these agencies prioritize drilling projects that address fundamental science objectives (e.g., IODP; International Continental Scientific Drilling Program: ICDP; USGS). Other agencies fund drilling projects that have more practical, applied science objectives, but which have collateral benefits for pure science investigations (e.g., US Department of Energy, US Department of Defense). Funding from these other agencies can be critical for many drilling projects, and may comprise the main or only funding for some projects. These projects have presented, and will continue to present, significant opportunities. An example of the opportunities provided by alternative funding sources is the Snake River Geothermal Drilling Project, funded by US Department of Energy, which produced $\sim 5.3 \mathrm{~km}$ of core (Shervais et al., 2013b).

\section{Fault zone processes and geomechanics}

The following three sections summarize the conclusions of the workshop regarding the key scientific objectives that are best addressed with CSD, and present specific project proposals that were prioritized by the attendees. Workshop participants discussed a wide range of proposed scientific drilling projects in all areas of active tectonics and magmatic systems. Of the projects presented in the white papers, some of these project proposals were deemed to be mature enough to proceed through the formal proposal process. Other proposals were judged to need more development before moving forward as formal proposals. The following assessment discusses both mature proposals and those deemed worthy of consideration but which require more development to move forward. Although certainly not an exhaustive list, several sites have been suggested as possibly fruitful drilling targets.
Several of the white papers represent mature proposals for which much of the preliminary site survey work is either in progress or has already been largely completed.

\subsection{Scientific objectives}

Workshop participants interested in active faulting recognized that the key scientific questions and hypotheses proposed in the white papers submitted to the workshop, and also those that are most topical among this research community at present, fall into two major topics: (1) understanding the seismic cycle and (2) long-term mechanical and structural evolution of fault zones. Scientific questions on understanding the seismic cycle include

1. How and why do earthquakes initiate? (white papers by Carpenter, and Savage)

2. What physico-chemical mechanisms control earthquake triggering and interaction? (white papers by Carpenter, Omura, Savage, and Singh)

3. What controls variations in faulting style and slip rates? (white papers by Carpenter, Hadizadeh, Reinen and Toy, and Lee)

4. Are there clear textural and mineralogical records that are diagnostic of the spectrum of faulting styles and slip rates? (white papers by Carpenter, Hadizadeh, Reinen and Toy, and Schleicher)

5. How do permeability, temperature, fluid pressure and flow, the stress field, and fault strength vary over the seismic cycle, and how are these controlled? (white papers by Carpenter, Christie-Blick, Kale, Kampman, Omura, Savage, Fulton, and Lee)

Scientific questions on long-term mechanical and structural evolution of fault zones include

1. How do faults act as barriers and conduits for fluids? How does this influence mineralization, heat transport, generation of damage zones, and migration and storage of multi-phase fluids $\left(\mathrm{H}_{2} \mathrm{O}, \mathrm{CO}_{2}, \mathrm{CH}_{4}, \mathrm{H}_{2}, \mathrm{He}\right.$, and magma) (white papers by Ball and Kampman)

2. How do the mantle, the lower crust, and upper crust interact? What are the avenues and rates of mass, heat, and fluid transport? (white papers by Ball, Kampman, Martel, Miller, and Lee)

3. How do geometry, composition, stress, deformation, and mechanical properties of fault zones evolve over geologic timescales? (white papers by Ball, ChristieBlick, Hadizadeh, Martel, Miller, and Lee)

The active faulting group prioritized several future drilling projects that propose to address the key topics outlined 
above. The first two of these fall into the understanding the seismic cycle topic and the last three are closely aligned with the long-term mechanical and structural evolution of fault zones topic. However, we emphasize that there are significant potential overlaps between all of the projects outlined below.

\subsection{Recommended projects: understanding the seismic cycle}

\subsubsection{Reoccupying and extending the SAFOD site (white papers by Carpenter et al. and Hadizadeh et al.)}

This project proposes to drill an additional multi-lateral borehole off the existing SAFOD main hole, to penetrate a repeating M2 earthquake patch (the Hawaii, HI, patch), for comparison with results already obtained within the creeping San Andreas Fault by SAFOD. Opportunities presented by these proposals include analyses of microstructure, physical properties, and deformational behavior of fault rocks from the seismically active fault zone, sampling of liquids and gases, and measuring physical conditions within the rupture patch of the recurring HI earthquake. This would include instrumenting the San Andreas Fault zone for long-term monitoring of seismicity, fluid pressure, temperature, and deformation during multiple cycles of the M2 repeating HI earthquake.

\subsubsection{Triggering earthquakes for science (white paper by Savage et al.)}

The physics of earthquake nucleation, propagation, and arrest, as well as the triggering of earthquakes both by distant earthquakes and by human activities, are important outstanding topics of current research. This project proposes to design and install an observatory consisting of surficial and borehole seismometers, as well as down-hole temperature, strain, and pore pressure sensors to make in situ measurements of variations in stress, strain, and fluid pressure in and near an active earthquake source. An earthquake occurring in the near field of this borehole observatory is critical to the success of this project. To increase the likelihood of recording an earthquake with this observatory, the project will trigger an earthquake within the observatory by pumping water into a fault at depth. Stimulating an earthquake within a certain area will mean the project does not need to penetrate a fault at natural nucleation depths, and therefore several fault-penetrating holes could be possible. The spatial coverage of the instrumental array would allow us to closely monitor all stages of the earthquake rupture process. Although no specific fault has been proposed at this time, several faults were suggested, mostly within the Basin and Range.

\subsection{Recommended projects: long-term mechanical and structural evolution of fault zones}

\subsubsection{Tectonic evolution and mechanics of the Rio Grande rift (white paper by Ball et al. and Martel)}

The Sangre de Cristo Fault (SCF) system accommodated late Quaternary extension in the northern Rio Grande rift. However, analysis of surficial geology and a wealth of geophysical data show that this structure is complex and has a long tectonic history. Scientific drilling through multiple and representative elements of the SCF presents opportunities to better understand the processes of fault system evolution within an intracontinental rift and provide an analog to other extensional systems. In situ fault zone characterization, rock sampling, hydraulic and thermal experimentation, and stress measurements would provide the subsurface ground truth and monitoring necessary to evaluate hypotheses on tectonic evolution, modern strain accommodation, and physical heterogeneity created by faults. Significantly, this project will develop results that address seismic hazard and groundwater resource exploitation in the wider Rio Grande rift region. Other sites within actively deforming regions of the Basin and Range, or the San Andreas Fault, could examine similar questions.

\subsubsection{Fluid flow and supercritical fluid-rock interactions in the Little Grand Wash fault (white paper by Kampman et al.)}

Geological carbon dioxide sequestration is an important target of ongoing research to which continental drilling can make a significant contribution. Degassing normal faults at Green River, Utah, are important analogs to seal bypass for engineered geological $\mathrm{CO}_{2}$ storage. Surface studies have provided important constraints on the $\mathrm{CO}_{2}$ source and the Quaternary degassing history of these faults, which imply large temporal variations in fault hydraulic behavior. Recent drilling at the site provided core and fluid samples that constrain fluid flow and fluid-rock reaction in the shallow subsurface $(\sim 300 \mathrm{~m})$. Deep drilling at depths $>800 \mathrm{~m}$, where the $\mathrm{CO}_{2}$ is supercritical, presents an opportunity to investigate how these mantle-derived volatiles react both within a fault damage zone and with the surrounding reservoir rocks and impermeable seals. In situ hydrological tests combined with geophysical imaging and geochemical monitoring would provide important constraints on the nature and rates of fracture-hosted two-phase flow. Mineralogical and petrophysical observations of the recovered core, combined with geochronological studies of fracture mineralization, would allow the long-term transmissivity of the faults to be assessed. 


\subsubsection{Mechanics of the Sevier detachment (white paper by Christie-Blick et al.)}

The Sevier Desert Detachment (SDD) accommodates normal slip of $<47 \mathrm{~km}$, with movement as recent as the Holocene $(<8 \mathrm{ka})$. It has been proposed that the SDD initiated at a dip of $\sim 11^{\circ}$, implying it has very low effective frictional strength, but the kinematics of the deformation remains controversial and the initiation of the fault obscure (ChristieBlick et al., 2009). Drilling aims to better characterize fault zone geometry, and to elucidate the mechanism(s) or physical conditions that result in weakness, providing insight into the formation of low-angle normal faults more generally. Magnetotelluric studies demonstrate fluids interact with the structure at depth, so this project also addresses fault-fluid interactions. An ICDP workshop has already been held to define both scientific objectives and a preliminary drilling plan, and this workshop group considers that pursuing the project further will address the aims of fault zone processes and geomechanics.

\subsection{Additional targets}

The following target sites and project ideas were also agreed to have significant scientific merit by the workshop participants. However, these proposals were considered less mature than those discussed above, and will require more development before they should move forward as full proposals.

- The interest in active basin and range deformation and fault mechanics in general (white papers by Martel; Omura; Miller and Lee; Savage et al.; Schmitt et al.; Toy et al.; Wannamaker et al.) suggests the need for collaborative teams to work on drilling projects that examine the mechanics of fault development, as well as earthquake rupture dynamics, the latter including rapidresponse drilling and determining post-slip temperature measurements within fault zones (e.g., Fulton et al., 2013).

- Dixie Valley (white paper by Wannamaker): an active Basin and Range fault with hydrothermal-magmatic interactions, possibly also induced seismicity. The fault is already being drilled in a project funded by US DOE, and it makes sense to take advantage of this campaign. However, slightly lower priority was assigned to this site because the same scientific questions are able to be addressed through drilling at the Rio Grande rift.

- The Snake Range Detachment fault zone (white paper by Miller and Lee) provides the opportunity to investigate the mechanical coupling between brittle and ductile crust - in particular, whether or not the footwall was rigid or experienced a form of channel flow/stretching during large-scale extension. A major question is, "how do the thermal structure of the crust and rates of ex- tension control the formation and evolution of this and similar deeply rooted detachment faults?"

- Mono Basin (white paper by Jayko et al.): drilling the tectonically and volcanically active Mono Basin to measure the stress field and evaluate the role of the Eastern Sierran frontal fault system in controlling the timing, location, and rates of magmatism and volcanism. These issues are crucial for defining the tectonics of the Walker Lane fault system, assessing the role of faults as conduits for magma, and for evaluating the geothermal energy potential in the area.

- The Puysegur Subduction Zone (white paper by Reinen and Toy): the young $(<11 \mathrm{Ma})$ crust of the incoming Australian Plate at this seismically active subduction zone has morphology indicating it may have peridotite at or very near the surface. Thus, it is very likely that the subduction thrust interface is within ultramafic rock containing serpentine. Serpentine has peculiar mechanical properties allowing it to slip seismically, or creep aseismically, depending on the imposed slip rate (e.g., Reinen et al., 1994; Reinen, 2000). This subduction zone is already instrumented by broadband seismometers and continuous GPS monitoring stations as part of the Geonet Network (http://info.geonet.org. nz/display/equip/Our+Equipment), so both seismic and aseismic slip distribution models can be constructed. However, densification of this network, which would allow significantly more precise analysis, should be undertaken. Also, there are a diverse range of groundshaking proxies on land in the Fiordland area (e.g., landslide records), and the area is subject to a proposal to collect a large transect of geophysical data under the GeoPRISMS initiative. This site therefore represents a good future opportunity to investigate how serpentine in particular plays a role in slip style and rate along major faults.

\section{Active magmatic systems}

\subsection{Scientific objectives}

Active volcanic systems are important to science and society - hazards to human populations associated with volcanic eruptions are significant in many parts of the world and have resulted in tens to hundreds of thousands of deaths. Understanding the life cycle of typical volcanic systems is crucial to managing the risk associated with their eruptions (Eichelberger and Uto, 2007). Active magmatic systems also drive hydrothermal circulation, which has been linked to exhalative and epithermal mineral deposits, and to high-enthalpy geothermal energy resources (Elders and Sass, 1988; Fournier, 1999; Eichelberger and Uto, 2007). These linkages provide the opportunity for multi-disciplinary studies that combine hazards analysis with both green energy and 
mineral resource research. Such linkages are critical to obtaining funding from a range of sources, thereby spreading both the risk and cost associated with drilling across several agencies or interest groups.

Outstanding questions related to active magmatic systems revolve around the fundamental issues of understanding how volcanoes work and constraining what hazards they may pose in the future, and can be summarized in five main categories below:

1. Volcano eruption cycle. What is the spatial and temporal evolution of magma migration and storage? What is the temporal evolution of eruption style? What are the systematic and asystematic aspects of eruption cycles?

2. Sustainability, stress, and recovery. How do eruption cycles integrate with ecological and local societal systems?

3. Eruption hazards. How can we improve short- and longterm eruption prediction? To what extent can we forecast near-field (e.g., lava flows, pyroclastic flows) and regional to global hazards (e.g., ash plumes)?

4. Verification of geophysical models. How reliable are estimates and uncertainties for internal processes and structures of volcanoes, determined from surface observations?

5. Interactions with other Earth systems. What are the potential climate impacts of volcanic eruptions? To what extent can volcanic systems help us understand tectonic and geodynamic processes?

\subsection{Recommended projects/sites: active magmatic systems}

\subsubsection{Okmok Volcano, Alaska, USA (white paper by Masterlink et al.)}

Okmok Volcano has produced two caldera-forming eruptions in the last 10000 years, along with frequent smaller eruptions. Okmok could serve as an interdisciplinary natural laboratory to address several relevant problems, which are transferrable to other volcanic systems. These include improving methods for identifying eruption history (timing, magnitude, and style) and constraining the rheological structure of shallow caldera regions and its influence on magma migration and storage. Key goals of the drilling project would include identifying eruptive materials comprising the shallow caldera, determining the rheologic structure of the shallow caldera, testing seismic tomography and magma migration models, quantifying related uncertainties, and characterizing, in space and time, stress and thermal regimes associated with the subsurface plumbing system.

\subsubsection{Aso Caldera, Japan (white paper by Nakada)}

Aso Caldera is a large caldera, which may be overdue for eruption. The scientific goals of drilling Aso Caldera include gaining a better understanding of the structural evolution of the last caldera eruption (controlled by a ring-fault zone on the caldera margin), temporal and spatial relationships of caldera collapse and climactic eruptions, precursory phenomena of climactic eruption events, environmental impact of eruptions on life and recovery, and determining the most effective monitoring and subsequent prediction techniques for associated hazardous volcanic events.

\subsubsection{Newberry Volcanic Monument, Oregon, USA (white paper by Frone)}

Newberry Volcano is one of the largest Quaternary volcanoes in the conterminous US; it covers $1600 \mathrm{~km}^{2}$ and has a volume of $450 \mathrm{~km}^{3}$ (MacLeod and Sherrod, 1988). It has experienced at least two caldera-forming eruptions $(\sim 300 \mathrm{ka}$ and $83 \pm 5 \mathrm{ka}$ ), and has had several other recent eruptions, including the $7 \mathrm{ka}$ (post-Mazama) sequence of dominantly basaltic andesite, and intra-caldera rhyolites, the youngest of which is $1.3 \mathrm{ka}$. Scientists are particularly interested in the depth, volume (estimated to be $1-8 \mathrm{~km}^{3}$ ), composition, and melt fraction of the proposed magma chamber at $3-6 \mathrm{~km}$ depth. Significant geophysical data have been collected to support drilling efforts at Newberry, including lidar, gravity, magnetotellurics, aeromagnetics, and seismic tomography. In addition at least two holes have been drilled already (to 932 and $424 \mathrm{~m}$ depth), from which useful data may be extracted without additional drilling operations.

\section{Geodynamic and geochemical evolution of Earth}

The geodynamic and geochemical evolution of the Earth are intimately linked to two dominant processes of heat transfer: plate tectonics (driven by the sinking of cold lithospheric plates in subduction zones and the rise of hot asthenospheric mantle below midocean ridges to form oceanic crust) and the rise of thermally (and possibly compositionally) buoyant mantle to form hotspots with their associated ocean island basalts and flood basalts. Together these dominant processes are responsible for the Wilson cycle, during which continents continually grow by collision and amalgamation.

\subsection{Science objectives - chemical geodynamics}

Research into Earth's chemical geodynamics discussed at the workshop can be divided into three focus areas that can be addressed by continental scientific drilling:

1. Large igneous provinces exposed on land, which are largely continental flood basalts but also include the emergent portions of oceanic LIPs. The current paradigm suggests that LIPs represent catastrophic 
melting of an engorged "plume head" at relatively shallow depths, whereas ocean island chains and continental hotspot tracks represent the plume "tails" (Hill, 1991, 1993);

2. Ocean island chains, which are thought to represent the active conduits of deep-seated mantle plumes erupted through oceanic lithosphere as it moves continuously over a relatively fixed thermal anomaly (hot spot);

3. Continental hotspot tracks, which are thought to represent the intracontinental equivalent of ocean island chains, and form as continental lithosphere moves continuously over the relatively fixed thermal anomaly.

Each of these focus areas engages a series of significant scientific questions that overlap in part, but also address some distinct issues. For example, continental flood basalts erupt over geologically short time spans and may have significant environmental impacts. But because they erupt through continental crust, their compositions are effected to various extents by interactions with subcontinental mantle lithosphere or continental crust. In contrast, ocean island chains erupt over prolonged time spans, but erupt through thin oceanic lithosphere, which has only minimal impact on their chemical and isotopic composition. Continental hotspot tracks erupt magmas that may be strongly affected by continental interaction, and their chemical and isotopic compositions may be decoupled (e.g., Hanano et al., 2008). Scientific issues addressed by CSD on LIPs, ocean island chains, and continental hotspots include the following:

- What are their modes of origin? How are they similar? How do they differ?

- What is the nature of the melting anomaly that produces LIPs and oceanic island chains? Is it heterogeneous spatially, or does it vary over time?

- What are the magma production and lava accumulation rates beneath each of these features? What is the duration of volcanism?

- What are the environmental impacts of LIP volcanism? Is LIP emplacement responsible for mass extinctions, oceanic anoxic events, etc.?

- How do the variations in magma chemistry, isotopic composition, and age of eruption constrain the dynamics of hotspot-continental lithosphere interaction?

- Can we establish geochemical and isotopic links between the plume head volcanic province and the plume tail province?

Workshop participants also endorsed the concept of integrated onshore-offshore studies that combine ICDP or other land-based projects on continental LIPs with IODP or special platform studies of ocean islands related to that LIP.

\subsection{Recommended projects: continental hotspot track}

Several high-priority projects were identified by the workshop participants, including projects that were recently drilled, or are currently being drilled, with non-NSF funding (ICDP, DOD, DOE, and international partners).

\subsubsection{Deccan Traps, India: US participation in the Indian Koyna Drilling Project and joint ICDP-IODP drilling of the Deccan-Reunion hotspot track (white papers by Kale, Neal)}

Onland drilling into the Deccan Traps flood basalt pile undertaken by the Koyna reservoir-induced seismicity project (Roy et al., 2013) can be expanded with further continental and ocean drilling. The Koyna project has drilled through the lava pile and into the underlying Precambrian gneiss, and there are plans to drill two more holes through the lava pile nearby. By combining additional continental drilling of the Deccan Traps in other locations with new drilling offshore along the hotspot trace, the plume hypothesis would be tested by evaluating the timing and extent of the change from plume head to plume tail magmatism, as well as investigating the heterogeneity of the two magma systems.

\subsubsection{Snake River Plain continental plume track (white papers by Christiansen, Shervais, Hanan, Potter, Schmitt, and Lee)}

The Snake River Plain (SRP) volcanic province represents the world-class example of time-transgressive intracontinental plume volcanism. The SRP is unique because it is young and relatively undisturbed tectonically, and because it contains a complete record of volcanic activity associated with passage of the hotspot, which can only be sampled by drilling. The central questions addressed by drilling the SRP are, (1) how do mantle hotspots interact with continental lithosphere, and (2) how does this interaction affect the geochemical evolution of mantle-derived magmas and continental lithosphere? At this time, three deep drill holes have been completed, with funding from ICDP, US DOE, and DOD. This project represents a prime example of the opportunities presented by intra-agency cooperation and joint support of projects by national and international funding sources (Shervais et al., 2013b).

\subsubsection{Other potential LIP flood basalt targets}

Participants identified additional potential targets for scientific drilling of LIPs and flood basalts, along with their related hotspot tracks. These include (1) the Etendeka-Walvis Ridge; this plume head-plume tail doublet in the South Atlantic Ocean formed coeval with the opening of the South Atlantic; (2) the Central Atlantic Magmatic Province (CAMP), which formed during the early opening of the central Atlantic Ocean, the first segment of the Atlantic Ocean to form, 
and a type locality for a "volcanic rifted margin" (this would require a joint onshore-offshore ICDP-IODP effort); and (3) the Ethiopian Traps, which represent the onset of LIP volcanism in a continental setting. They form our best modern example of LIP volcanism, and can be related to rift zone volcanism to the south, and ocean basin formation to the north.

\subsection{Recommended projects: ocean islands - the oceanic record of plume tail volcanism}

In order to evaluate geochemical and isotopic components of mantle geodynamics, it is necessary to obtain samples that have not been contaminated by continental crust, which has extreme chemical and isotopic compositions that can mask the more subtle mantle signatures. This is traditionally approached by sampling "plume tail" hotspot tracks that penetrate oceanic crust. Because the oceanic crust is thin and compositionally similar to plume-derived basalts, this minimizes contamination and allows detailed evaluation of the mantle component. Two projects are highlighted here Mauna Loa and Mauna Kea - and two other locations were found promising: Reunion (with its tie-in to Deccan drilling) and Kerguelan, a major oceanic plateau in the southern Indian Ocean.

\subsubsection{Mauna Kea Pöhakuloa Training Area (PTA) project (white paper by Garcia)}

The Mauna Kea Pöhakuloa Training Area (PTA) project represents an unprecedented opportunity to gain a more detailed record of a Hawaiian volcano. Under this project, the US Army has funded $(\sim \$ 6 \mathrm{M})$ the drilling of two, $\sim 2000 \mathrm{~m}$ deep boreholes in search of water on the upper flank of Mauna Kea Volcano on the Island of Hawai'i. The first hole, located $\sim 10 \mathrm{~km}$ from the volcano's summit, was completed to a depth of $\sim 1760 \mathrm{~m}$ with a high rate of recovery $(>90 \%)$. Drilling and coring of the second hole is scheduled to start before the end of 2013. Both holes will be cored continuously to total depth, and the core is being curated by the University of Hawai'i. These two holes provide a rare prospect for detailed examination of the volcanic history of a Hawaiian volcano and will allow many important issues to be examined, including the following. (1) What are the magma production and lava accumulation rates for Hawaiian volcanoes? (2) What is the scale of heterogeneity and variation in partial melting within the Hawaiian plume? (3) What is the nature of the transition from shield to post-shield volcanism? (4) How do Hawaiian and other volcanoes grow? (5) What is the heat flow within an oceanic volcano (e.g., conductive, or convective and controlled by ground water)? (6) What is the extent of explosive volcanism for Hawaiian volcanoes?

\subsubsection{Mauna Loa Project (white paper by Rhodes)}

The most important recent result of Hawaiian studies is resurrection of the concept of an asymmetrical mantle plume in which volcanoes along two en echelon trends, the Loa and Kea trends, exhibit distinct major element and isotopic compositions (Abouchami et al., 2005; Weis et al., 2011). This asymmetry in plume source components is attributed to asymmetry in the lowermost mantle preserved in the melting zone within the plume (Weis et al., 2011; Farnetani et al., 2012). Loa trend magmas are thought to contain a greater contribution of recycled crustal material than those of Kea trend volcanoes. An unresolved and contentious problem is whether Loa magmas result from melting discrete lithological domains (i.e., pyroxenite/eclogite) of this crustal material within the plume, or whether they reflect melting of peridotite fertilized by pyroxenite/eclogite melts (Jackson et al., 2012). To understand Hawaiian volcano growth, melt production, and the identity, composition, and lithology of plume components it is necessary to core a Loa trend volcano to obtain comparable information to that obtained by the Hawaiian Scientific Drilling Project for Mauna Kea, which is a Kea trend volcano (Stolper et al., 2009). Mauna Loa, the world's largest active volcano $\left(\sim 100000 \mathrm{~km}^{3}\right)$, is the obvious candidate because a great deal more is known of its recent sub-aerial history $(<120 \mathrm{ka})$ and also of its earlier (>400 ka) submarine growth than other Loa trend volcanoes (Rhodes, 2014).

\subsection{Science objectives - subduction systems}

The large-scale evolution of subduction zones in relation to volcanic arcs is fundamental to understanding how continental crust forms. Some of the questions to be addressed by drilling within subduction systems include

- What magmatic processes create intermediatecomposition magmas?

- What roles do lateral accretion and magmatic intrusion play in the growth of arc-related crust?

- Is the lower mafic crust of the arc recycled back into the mantle and, if it is, how is this accomplished?

- How much of the magma at a convergent margin is new juvenile addition to the crust and how much is recycled older crust?

- What causes the intrinsically high water and oxygen fugacities of arc magmas?

There are many questions about how arcs form and evolve that can only be addressed by drilling projects, especially those that look at the life cycle of magmatic arcs whose older roots are buried by younger activity.

Most drilling activity related to subduction systems will be carried out by IODP, because active subduction systems 
at depths that can be accessed by drilling are found primarily below the oceans. However, there are portions of some active systems, as well as many fossil systems, that are found on land. Some of these areas are the subject of the ExTerra initiative of the NSF GeoPRISMS program. The ExTerra initiative seeks to understand subduction dynamics by investigating exposed portions of active systems or a few wellpreserved fossil systems. For example, drilling an exposed supra-subduction zone mantle wedge can provide continuous core through this system, which would be impossible to obtain from an active fore-arc. Further, drilling projects can be combined with surface mapping and geophysics to build a detailed 3-D model of mantle wedge architecture. Rock properties can be studied on recovered core and at the outcrop scale, and then scaled up using surface mapping, surface-based geophysical transects, vertical seismic profiles, or cross-hole experiments to provide more realistic constraints than possible using lab studies alone. Finally, if the core can be oriented relative to Earth's magnetic field, then intrinsic properties such as rock magnetism and latticepreferred orientation fabrics can be measured and compared to experimental results on fabric development and seismic anisotropies observed in subduction systems.

\subsection{Recommended projects - subduction systems}

\subsubsection{Josephine Ophiolite - direct observation of a sub- duction zone mantle wedge (Shervais and Dick white paper)}

Characterization of geochemical flux in the mantle wedge during subduction is critical to our understanding of arc volcanism, and forms an important aspect of the global geochemical flux. Drilling is needed to provide unweathered samples of mantle wedge peridotites that represent vertical transects of the mantle. The Josephine Ophiolite, California, preserves the largest exposed tract of mantle peridotite in North America, and represents the fore-arc of a paleoCascadia subduction zone. Microstructures and macrostructures that document deformation processes in the mantle wedge are well preserved, along with alteration and mineralization that document low- to intermediate-temperature metamorphism within the mantle wedge. Major questions that can be addressed by drilling include the cumulative extent of melt extraction phases and the nature of the melt extracted, the nature and extent of mantle-melt interactions subsequent to melt extraction (e.g., addition of melt from deeper in the asthenosphere), and the nature, source, and extent of fluid flux to SSZ peridotites. The resulting drill holes can also be used to make in situ measurements of mantle wedge physical properties, e.g., using vertical seismic profiles or crosshole seismic experiments.

\subsubsection{The Puysegur Subduction Zone (white paper by Reinen and Toy)}

The Puysegur Subduction Zone was discussed earlier under fault zone processes; it also represents an ideal location for the study of chemical geodynamics in the mantle wedge.

\section{Technology issues}

There are a number of technology issues that are critical for many of the drilling initiatives proposed here, and more generally for future scientific drilling projects worldwide. Some of these technological requirements are specific to certain environments (e.g., high temperatures in active magmatic systems), while others affect a range of drilling environments and project types. Areas in which technological advances are needed include the following:

- Downhole observatories. Permanent or semi-permanent downhole observatories to measure temperature, strain, fluid pressure or seismic activity are critical to the success of many drilling projects. For many of these observatories, drilling the hole is often the most expensive part of the operation, and installation of downhole observatories can be a cost-effective way to maximize scientific return. To be successful, it is necessary to develop robust sensors and deployment systems that can survive temperatures $>120^{\circ} \mathrm{C}$ and under chemically hostile conditions.

- High-temperature downhole logging tools $\left(>150^{\circ} \mathrm{C}\right)$ for use in small-diameter holes ( $<15 \mathrm{~cm}$ diameter). Although tools suitable for use in large-diameter holes are available that can operate at temperatures up to $300^{\circ} \mathrm{C}$, current slim-hole tools operate above $70^{\circ} \mathrm{C}$ or $140^{\circ} \mathrm{C}$, which limits our ability to study active magmatic systems, active fault zones, geothermal settings, or other high-heat flow regimes using small-diameter (exploratory) drill holes.

- Improved gas and fluid sampling tools (downhole) for slim drill holes. Obtaining gas-saturated water samples from slim holes ( $<15 \mathrm{~cm}$ diameter) is a delicate operation that takes considerable rig time (e.g., $12 \mathrm{~h}$ per run) and is often unsuccessful. Because water and gas chemistry is critical in many studies, more reliable and costeffective tools for borehole liquid and gas sampling are critical.

- Drilling and completion technologies. Drilling/coring techniques, directional control, downhole measurements, and casing/cementation should be developed and modified to maximize success in highly deformed and unstable fault zone environments. 


\section{Summary and recommendations}

Workshop participants discussed the significant science issues addressed by a targeted program of continental scientific drilling of faults, fault zones, volcanoes, and volcanic terranes, and specific targets that can best answer these questions. The scientific questions and targets discussed here align with the priorities specified in the recent National Research Council report "New Research Opportunities in the Earth Sciences" (NRC, 2012), as well as previous NRC reports (NRC, 2008, 2011).

Linkages between ICDP, IODP, and national science agencies are critical for a successful continental scientific drilling program because resources can be leveraged across programs and between countries to maximize return on investment for all participants. Recent examples of inter-agency and international efforts include the Chesapeake Bay Drilling Project (USGS, ICDP), the San Andreas Fault Observatory at Depth (NSF, USGS, ICDP, and various international funding agencies), the Snake River Drilling Project (DOE, ICDP, USAF), and the PTA drilling project on Mauna Kea (US Army, NSF). Additional linkages should be sought with industries that rely on drilling, as has been the case for numerous drilling projects carried out in the US and internationally that have addressed themes relevant to the petroleum and geothermal industries (e.g., the Iceland Deep Drilling Project).

Participants working on faults and fault zone processes highlighted two overarching topics: (1) understanding the seismic cycle and (2) long-term mechanical and structural evolution of fault zones. Five projects were recommended for consideration at this time: reoccupying and extending the SAFOD site; triggering earthquakes for science; mechanics of the Sevier detachment; tectonic evolution and mechanics of the Rio Grande rift; and fluid flow and supercritical fluidrock interactions in the Little Grand Wash fault. Participants working on tectonics, magmatic activity, and active volcanism defined three dominant themes: volcanic and subvolcanic processes, hazards assessment, and resources. Four projects were recommended for consideration at this time. The recommended projects are Okmok Volcano, Alaska, USA; Aso Caldera, Japan; Mount St. Helens, Washington, USA; and Newberry Volcanic Monument, Oregon, USA. Participants working on chemical geodynamics highlighted five projects: Deccan Traps (potentially joint ICDP-IODP drilling of the Deccan-Reunion Hotspot track); Snake River Plain Continental Plume Track; Mauna Kea PTA project; Mauna Loa Project; and the Josephine Ophiolite - Direct Observation of a Subduction Zone Mantle Wedge.

Technology issues addressed include borehole observatories, new tools for oriented core, robust downhole tools for high-temperature or caustic environments, improved tools for liquid and gas sampling, and improved drilling and completion technologies.

Finally, participants emphasized the importance of cultivating early-career scientists and other young researchers, who will have to initiate and carry out many of the research programs defined at the workshop. Involvement of young scientists and, if possible, graduate students who are near completion of their $\mathrm{PhD}$ programs will have an enormous impact on their future research success, as well as on the continued success of continental scientific drilling. They will also bring new ideas to the table that will impact current projects, and those already in process. The preparation and education of the geoscience workforce has a high priority in industry and academia, and the implementation of strong scientific drilling projects will enhance these goals.

Acknowledgements. This workshop was conducted with support of the US National Science Foundation (EAR-1313603). Any opinions, findings, and conclusions or recommendations expressed in this material are those of the authors and do not necessarily reflect the views of the US National Science Foundation. We thank the members of the Drilling, Observation, and Sampling of Earth's Continental Crust (DOSECC) Science Planning Committee for initial planning and support. We also wish to thank Kristina Glaittli of Utah State University and the staff at Treasure Mountain Inn for logistical support. Finally, we express deep thanks to all of the workshop participants, for their considerable investment of time and effort.

Edited by: T. Morishita

Reviewed by: one anonymous referee

\section{References}

Abouchami, W., Hofmann, A. W., Galer, S. J. G., Frey, F. A., Eisele, $\mathrm{J}$., and Feigenson, $\mathrm{M} . \mathrm{Pb}$ isotopes reveal bilateral asymmetry in the Hawaiian plume, Nature, 434, 851-856, 2005.

Ando, M.: Geological and geophysical studies of the Nojima Fault from drilling: An outline of the Nojima Fault Zone Probe, Island Arc, 10, 206-214, 2001.

Chester, F. M., Rowe, C., Ujiie, K., Kirkpatrick, J., Regalla, C., Remitti, F., Moore, J. C., Toy, V., Wolfson-Schwehr, M., Bose, S., Kameda, J., Mori, J. J., Brodsky, E. E., Eguchi, N., Toczko, S., and Expedition 343 and 343T Scientist: Structure and Composition of the Plate-Boundary Slip Zone for the 2011 Tohoku-Oki Earthquake; Science, v342, no. 6163, 1208-1211, doi:10.1126/science.1243719, 2013.

Christie-Blick, N., Anders, M. H, Manatschal, G., and Wernicke, B. P.: Testing the Extensional Detachment Paradigm: A Borehole Observatory in the Sevier Desert Basin, Sci. Dril., 8, 57-59, doi:10.5194/sd-8-57-2009, 2009.

DePaolo, D. J. and Weis, D.: Hotspot volcanoes and large igneous provinces, in: Continental scientific drilling: A decade of progress and challenges for the future, edited by: Harms, U., Koeberl, C., and Zoback, M. D., Berlin, Heidelberg, New York, Springer, 259-288, 2007.

DePaolo, D. J., Stolper, E. M., Thomas, D. M. et al.: The Hawaii Scientific Drilling Project: Summary of Preliminary Results, GSA Today, 6, 1-8, 1996. 
DePaolo, D. J., Stolper, E. M., and Thomas, D. M.: Scientific Drilling In Hotspot Volcanoes, in: McGraw-Hill Yearbook of Science and Technology 2007, 203-205, 2007.

Eichelberger, J. C. and Uto, K.: Active volcanic systems, in Harms, U., Koeberl, C., and Zoback, M. D.: Continental scientific drilling: A decade of progress and challenges for the future, Berlin, Heidelberg, New York, Springer, 215-234, 2007.

Elders, W. A. and Sass, J .H.: The Salton Sea scientific drilling project, J. Geophys. Res., 93, 12953-12968, 1988.

Elders, W. A., Friðleifsson, G. O., and Bjarni Pálsson, B.: Iceland Deep Drilling Project: The first well, IDDP-1, drilled into magma, Geothermics, 49, 1, doi:10.1016/j.geothermics.2013.08.012, 2014.

Erba, E., Bottini, C., Weissert, H. J., and Keller, C. E.: Calcareous nannoplankton response to surface-water acidification around Oceanic Anoxic Event 1a; Science, 329, 428-432, doi:10.1126/science.1188886, 2010.

Farnetani, C. G., Hofmann, A. W., and Class, C.: How double volcanic chains sample geochemical anomalies from the lowermost mantle, Earth Planet Sci. Lett., 298, 240-247, 2012.

Fournier, R. O.: Hydrothermal processes related to movement of fluid from plastic into brittle rock in the magmatic-epithermal environment, Econ. Geol., 94, 1193-1211, 1999.

Friðleifssona, G. Ó., Elders, W. A., and Albertsson, A.: The concept of the Iceland deep drilling project, Geothermics, 49, 2-8, doi:10.1016/j.geothermics.2013.03.004, 2014.

Fulton, P. M., Brodsky, E. E., Kano, Y., Mori, J., Chester, F., Ishikawa, T., Harris, R. N., Lin, W., Eguchi, N., Toczko, S., and Expedition 343, 343T, and KR13-08 Scientists: Low Coseismic Friction on the Tohoku-Oki Fault Determined from Temperature Measurements, Science, 1214-1217, doi:10.1126/science.1243641, 2013.

Harms, U., Koeberl, C., and Zoback, M. (Eds.): Continental Scientific Drilling, A Decade of Progress and Challenges for the Future, Berlin, Heidelberg, New York, Springer, 238 pp., 2007.

Hanano, D., Weis, D., Scoates, J. S., Aciego, S., and DePaolo, D. J.: Horizontal and vertical zoning of heterogeneities in the Hawaiian mantle plume from the geochemistry of consecutive post-shield volcano pairs: Kohala-Mahukona and Mauna Kea-Hualalai, Geochem. Geophy. Geosy., 11, Q01004, doi:10.1029/2009GC002782, 2010.

Hill, R. I.: Starting plumes and continental breakup, Earth Planet. Sci. Lett., 104, 398-416, 1991.

Hill, R. I.: Mantle plumes and continental tectonics, Lithos, 30, 193-206, 1993.

Ito, H., Behrmann, J., Hickman, S., Tobin, H., and Kimura, G. (Eds.): Report from IODP/ICDP workshop on fault zone drilling, Miyasaki, Japan, 2006: Scientific Drilling, Special Issue 1, 2007.

Jackson, M. G., Weis, D., and Huang, S.: Major element variation in Hawaiian shield lavas: Source features and perspectives from global ocean island (OIB), Geochem. Geophy. Geosy., 13, 15252027, doi:10.1029/2012GC004268, 2012.

Ma, K.-F., Lin, Y.-Y., Lee, S.-J., Jim Mori, J., and Brodsky, E. E.: Isotropic Events Observed with a Borehole Array in the Chelungpu Fault Zone, Taiwan, Science, 337, 459-462, 2012.

Ma, K.-F., Tanaka, H., Song, S.-R., Wang, C.-Y., Hung, J.-H., Tsai, Y.-B., Mori, J., Song, Y.-F., Yeh, E.-C., Soh, W., Sone, H., Kuo L.-W., and Wu, H.-Y.: Slip zone and energetics of a large earth- quake from the Taiwan Chelungpu-fault Drilling Project, Nature, 444, 473-476, doi:10.1038/nature05253, 2006.

MacLeod, N. and Sherrod, D.: Geologic evidence for a magma chamber beneath Newberry Volcano, Oregon, J. Geophys. Res., 93, 148-227, doi:10.1029/88JB00273, 1988.

Nakada, S., Uto, K., Sakuma, S., Eichelberger, J. C., and Shimizu, H.: Scientific Results of Conduit Drilling in the Unzen Scientific Drilling Project (USDP), Sci. Dril., 1, 18-22, doi:10.5194/sd-118-2005, 2005.

NCR (National Research Council): Origin and Evolution of Earth: Research Questions for a Changing Planet, National Academy Press, 200 pp., 2008.

NCR (National Research Council): Understanding Earth's Deep Past: Lessons for our Climate Future, National Academy Press, Washington DC, 140 pp., 2011.

NCR-NROES (National Research Council): New research opportunities in the Earth Sciences, National Academy Press, 174 pp., 2012.

Neal, C. R., Coffin, M. F., Arndt, N. T., Duncan, R. A., Eldholm, O., Erba, E., Farnetani, C., Fitton, J. F., Ingle, S. P., Ohkouchi, N., Rampino, M. R., Reichow, M. K., Self, S., and Tatsumi, Y.: Investigating Large Igneous Province Formation and Associated Paleoenvironmental Events: A White Paper for Scientific Drilling, Sci. Dril., 6, 4-18, doi:10.5194/sd-6-4-2008, 2008.

Reinen, L. A.: Seismic and aseismic slip indicators in serpentinite gouge, Geology, 28, 135-138, 2000.

Reinen, L. A., Weeks, J. D., and Tullis, T. E.: The frictional behavior of lizardite and antigorite serpentines - experiments, constitutive models, and implications for natural faults, Pure Appl. Geophys., 143, 317-358, 1994.

Rhodes, J. M.: Major element and isotopic variations in Mauna Loa magmas over $600 \mathrm{ka}$ : Implications for magma generation andsource lithology as Mauna Loa transits the Hawaiian plume, AGU Monograph, Chapman Conf. on Hawaiian volcanism, submitted, 2014.

Roy, S., Rao, N. P., Akkiraju, V. V., Goswami, D., Sen, M., Gupta, H., Bansal, B. K., and Nayak, S.: Granitic Basement below Deccan Traps Unearthed by Drilling in the Koyna Seismic Zone, Western India, Journal Geological Society of India, 81, 1-2, 2013.

Shervais, J. W., Branney, M. J., Geist, D. J., Hanan, B. B., Hughes, S., Prokopenko, A. A., and Williams, D. F.: HOTSPOT: The Snake River Scientific Drilling Project -Tracking the Yellowstone Hotspot Through Space and Time, Sci. Dril., 3, 56-57, doi:10.5194/sd-3-56-2006, 2006.

Shervais, J. W., Evans, J. P., Clark, A., and Eichelberger, J. C., Kirkpatrick, J., and Toy, V.: White Papers: Drilling Active Tectonics and Magmatism (Volcanics, Geoprisms, and Fault Zones Post-SAFOD): Geology Faculty Publications, Paper 386, http: //digitalcommons.usu.edu/geology_facpub/386, 2013a.

Shervais, J. W., Schmitt, D. R., Nielson, D., Evans, J. P., Christiansen, E. H., Morgan, L., Pat Shanks, W. C., Prokopenko, A. A., Lachmar, T., Liberty, L. M., Blackwell, D. D., Glen, J. M., Champion, L. D., Potter, K. E., and Kessler, J. A.: First Results from HOTSPOT: The Snake River Plain Scientific Drilling Project, Idaho, U.S.A., Sci. Dril., 15, 36-45, doi:10.5194/sd-1536-2013, 2013b. 
Stolper, E. M., DePaolo, D. J., and Thomas, D. M.: Deep Drilling into a Mantle Plume Volcano: The Hawaii Scientific Drilling Project, Sci. Dril., 7, 4-14, doi:10.5194/sd-7-4-2009, 2009.

Tejada, M. L. G., Suzuki, K., Kuroda, J., Coccioni, R., Mahoney, J. J., Ohkouchi, N., Sakamoto, T., and Tatsumi, Y.: Ontong Java Plateau eruption as a trigger for the early Aptian oceanic anoxic event, Geology, 37, 855-858, doi:10.1130/G25763A.1, 2009.

Tobin, H., Kinoshita, M., Ashi, J., Lallemant, S., Kimura, G., Screaton, E. J., Moe, K. T., Masago, H., Curewitz, D., and the Expedition 314/315/316 Scientists: NanTroSEIZE Stage 1 expeditions: introduction and synthesis of key results, edited by: Kinoshita, M., Tobin, H., Ashi, J., Kimura, G., Lallemant, S., Screaton, E. J., Curewitz, D., Masago, H., Moe, K. T., and the Expedition 314/315/316 Scientists, Proc. IODP, 314/315/316: Washington, DC (Integrated Ocean Drilling Program Management International, Inc.), 2009.

Tobin, H. J. and Kinoshita, M.: Investigations of seismogenesis at the Nankai Trough, Japan, IODP Sci. Prosp., NanTroSEIZE Stage 1, doi:10.2204/iodp.sp.nantroseize1.2006, 2006.
Townend, J., Sutherland, R., and Toy, V.: Deep Fault Drilling Project - Alpine Fault, New Zealand, Sci. Dril., 8, 75-82, doi:10.5194/sd-8-75-2009, 2009.

Weis, D., Garcia, M. O., Rhodes, J. M., Jellinek, M., and Scoates, J. S.: Role of the deep mantle in generating the compositional asymmetry of the Hawaiian mantle plume, Nat. Geosci., 4, 831838, 2011.

Xu, X., Wen, X., Yu, G., Chen, G., Klinger, Y., Hubbard, J., and Shaw, J.: Coseismic reverse- and oblique-slip surface faulting generated by the $2008 \mathrm{Mw} 7.9$ Wenchuan earthquake, China, Geology, 37, 515-518, doi:10.1130/G25462A.1, 2009.

Zoback, M., Hickman, S., Ellsworth, W., and the SAFOD Science Team: Scientific Drilling Into the San Andreas Fault Zone - An Overview of SAFOD's First Five Years, Sci. Dril., 11, 14-28, doi:10.5194/sd-11-14-2011, 2011.

Zoback, M. D., Hickman, S., and Ellsworth, W.: Scientific Drilling into the San Andreas Fault Zone: EOS, Transactions, American Geophysical Union, 91, 197-199, 2010. 